\title{
Singapore Cinema in Search of Identity
}

\author{
By Yvonne Ng
}

Spring 2001 Issue of KINEMA

\section{IT HAS BEEN TEN YEARS SINCE FILM PRODUCTION IN SINGAPORE WAS RE-} VIVED IN 1991

after being dormant for almost two decades. At the time, in the 70s and 80s, the city-state was probably the only country in Southeast Asia without a film-making industry of its own. Then again, it hadn't been an independent republic for very long. A former British colony, it became self-governing in 1959. Following a short-lived association with the Federation of Malaysia, the city found itself a fully independent and sovereign nation in 1965. For the next twenty years, the government devoted itself to the task of nation-building and the challenge of changing the island's status from a developing country to that of a newly industrialised one.

By the start of the 90s, it was clear that the goal of economic prosperity had been achieved. At the same time, it was equally obvious that in the pursuit of material wealth, which meant focussing mainly on science and technology, little, if any, thought had been dedicated to the arts. The term "cultural desert" inevitably found its way into any discussion about the finer things in life. The authorities, ever pragmatic, decided there was economic value in artistic activity and determined to transform Singapore into a "vibrant global city of the arts".

However, it was not until1997 that film was officially recognized as an art form by the National Arts Council, joining the more established disciplines of theatre, music, dance, literature, photography and the visual arts. By then, a handful of films had been locally produced, including Eric Khoo's R(A)-rated psychological drama Mee Pok Man (1995) the first Singapore feature in this initial phase of experimentation to show artistic promise and Ong Keng Sen's Army Daze (1996), a comedy which was by no means a breakthrough but which found box-office success at home. Only two other films were made between 1991 and 1997: the pioneering movie Medium Rare (1991), a work so dismal in quality the authorities tried to distance themselves from it half way through production; and Bugis Street (1995), an exploitative film about the city's transvestites and transsexuals in the city's former red-light district.

In 1997, three new productions materialized. Among these were The Road Less Travelled by Lim Suat Yen, the first feature to be shot entirely in Mandarin in 20 years and Eric Khoo's 12 Storeys, a down-to-earth portrayal of loneliness and alienation set in a public housing block. The film won the director critical acclaim and became the first feature from the city to be shown in Cannes. Although film production was gaining momentum among local enthusiasts, a persistent and pressing problem was the lack of funding for young filmmakers. The films produced in 1997, for example, were all privately financed, and ranged from 12 Storeys' budget of $\mathrm{S} \$ 300,000$ to over $\mathrm{S} \$ 1$ million for Hugo Ng's God or Dog.

The launch of the Singapore Film Commission (SFC) in April 1998 signalled that the government was serious about developing a national film industry, and was ready, in its customary, cautious way, to provide financial assistance to deserving filmmakers. Scripts considered likely to be successful are now funded through loans of up to $\mathrm{S} \$ 250,000$ and $\mathrm{S} \$ 5,000$ grants are offered to successful short film applicants.

Meanwhile, 1998 saw the release of four films, all made without government funding. Glen Goei's Forever Fever, a romantic comedy inspired by the 70s'musical Saturday Night Fever, cost S $\$ 1.5$ million to produce and was picked up by Miramax Films for $\mathbf{S} \$ 4.5$ million. It was released in the United States under the title That's the Way I Like it, becoming the first Singapore production to find a market outside of Asia. The overwhelming surprise success of the year, however, was the $\$ \$ 850,000$ Money No Enough by Tay Teck Lock. Making a timely appearance at the peak of the Asian economic crisis, this slice-of life comedy about the financial predicament of three friends grossed $\mathrm{S} \$ 5.84$ million in four months. It was also the first time a film shot almost entirely in one of the local dialects (Hokkien, in this case) was allowed to pass intact, clearing the path for other home productions to use dialect and Singlish (a mix of vernacular English, Malay and Chinese). Official policy usually requires that films in dialect, such as Cantonese movies from Hong Kong, be dubbed into Mandarin for exhibition in Singapore. 
As expected, the box-office triumph of Money spurred the confidence of film investors, resulting in a record number of domestic productions the following year. Anticipation, however, soon gave way to consternation as one film after another either turned out to be clones of Money No Enough or were simply not good enough. The only home production of consequence in 1999, and one of the best Singapore films of the decade was Eating Air, released in December and would have been the first to be supported by the Film Commission had the directors not found private investment elsewhere. Eating Air, an original, bittersweet portrayal of a group of teenagers on motorbikes was made by film critic Kelvin Tong and film editor Jasmine Ng for a modest $\mathbf{S} \$ 800,000$, including advertising costs. In four weeks, it took in all of $\mathbf{S} \$ 350,000$.

In fact, out of the eight films that made it to the big screen that year (from an initial prediction of twelve), only one, Liang Po Po The Movie directed by Teng Bee Lian, managed a decent profit. It, however, had the benefit of an aggressive and sophisticated publicity campaign, unprecedented for a Singapore production. This $\mathrm{S} \$ 800,000$ gangster comedy, based on a cross-dressing TV character, collected $\mathrm{S} \$ 3.03$ million, making it the third highest grossing film of the year. A joint effort with director Eric Khoo's Zhao Wei Films, Liang Po Po was the first feature of Raintree Pictures, the filmmaking subsidiary of the Television Corporation of Singapore, and at present the most active feature film producer in the city . Raintree's objective is to make mainstream "borderless" movies that will appeal to Asian and even international markets. In attempting this goal, one strategy has been to employ well-known regional performers, starting with Liang Po Po with stars from Hong Kong and Malaysia. Another has been to engage in regional co-productions, as was the case in the company's second film, The Truth about Jane and Sam (1999). This feature was made in collaboration with Hong Kong filmmaker Derek Yee who also wrote and directed the film about the romance between a pair of mismatched characters. Taiwanese singer Peter Ho played a Singaporean reporter while Singaporean TV star Fann Wong took on the role of a Hong Kong delinquent. The $\mathbf{S} \$ 800,000$ movie recouped S $\$ 1.06$ million, and was also released in Malaysia, Taiwan and China.

For their next film, Raintree turned towards the international arena with 2000AD, released in February 2000. The movie was co-produced with Hong Kong's Media Asia Films, directed by Hong Kong's Gordon Chan, and endowed with the glamour of Hong Kong singer Aaron Kwok leading a cast from Singapore, Hong Kong and Taiwan. The $\mathrm{S} \$ 6.3$ million action thriller about the Y2K bug boasted a script adapted from an original screenplay by American writer Stu Zicherman and special effects by the team behind the Hollywood blockbuster Independence Day. Despite the expansive publicity and star power, the film took in just $\$ 900,000$ at home. However, with luck on their side, the producers have managed to sell it not only to other Asian countries, parts of Europe but also to Miramax Films for the North American market.

The eagerness to find audiences beyond Singapore is due to the general sentiment that the island's population of less than four million is too small to sustain a profitable national film industry. The urgency to go global has been compounded by falling cinema attendances across the island. Although the Republic has had one of the highest annual per capita cinema attendance rates in the world, peaking in the 1970s at around 19.3 per inhabitant, the figure has been declining steadily, hitting 5.2 with the financial crisis in 1998; today the figure would be around 4. Film exhibitors have tried to draw the crowds back with plush, new multiplexes, increased convenience in booking tickets and even lower admission fees. Nevertheless, a number of multiplexes and older cinema halls have seen their curtains fall.

The decline has been blamed on the Asian problem of VCD (Video Compact Disc) piracy which exhibitors claim have cut into 25 to $30 \%$ of the box-office returns. In addition, movie-going now has to compete with new leisure options such as the Internet, computer gaming centres or hanging out at one of the many trendy coffee outlets that have emerged. Another contributing factor is the fact that film viewers now seem to have less rather than more choice despite some 170 screens on the island. Kenneth Tan, chairman of the Singapore Film Society and now head of MediaCorp, the largest local media company, claims VCD piracy has forced distributors to open their films "wide and quick", on as many screens as possible and as close to the US release date as possible. This means that at any one time, the number of commercial movies on theatrical release is very limited.

One way young Singapore filmmakers have countered rising production costs and declining ticket sales is by switching to digital video, a format which is much cheaper to use than $35 \mathrm{~mm}$ film and therefore kinder to experimentation and the trial-and-error of novice filmmakers and inexperienced actors. The first digital film 
shot here was Stamford Hall, an unreleased comedy made for $\mathbf{S} \$ 18,000$ by a group of university students. The second was Stories about Love, a feature comprising three segments, each written and directed by a different filmmaker. A fully digital venture, it employed digital cameras, editing systems and a digital projector specially installed for the movie's commercial release. The $\mathbf{S} \$ 300,000$ feature was bankrolled by Cyberflics, a new company set up by Geoff Malone, founder of the Singapore International Film Festival, and hotelier Andrew Yap. Filmmaker Eric Khoo served as producer. After a one-week screening, Stories collected just $\mathrm{S} \$ 50,000$. A third digital feature, Return to Pontianak, is set to be released in the first quarter of 2001. Written and directed by Djinn, this tale of misadventure inspired by the popular "pontianak" (female vampire) local horror sub-genre of the 1950s and 60s, is about a group of young people who set out to find a lost Malay village. The digital film cost $\mathrm{S} \$ 180,000$ and is produced by Vacant Films.

After making films looking like imitations of Hong Kong productions, Raintree Pictures is now concentrating on subjects closer to home. The end of 2000 saw the movie company's first English production, Chicken Rice War. This comedy cooks up an unlikely combination of chicken rice and Shakespeare as it portrays the budding romance between the offsprings of two feuding food stall owners. Directed by Cheah Chee Kong (CheeK) who also made one of the episodes for Stories about Love, the $\mathbf{\$} \$ 800,000$ film is the first to be funded by the SFC with an investment of $\mathbf{S} \$ 250,000$. Raintree financed the remaining $\mathbf{S} \$ 550,000$. After playing for three weeks, the film managed only about $\mathrm{S} \$ 400,000$ in box-office takings.

If the glossy, star-studded Hollywood and Hong Kong productions are having a hard time attracting Singapore audiences, the difficulty is multiplied many times over when it comes to local productions. The type of domestic fare being provided has been limited by tight budgets, repetitive subjects and styles, dubious performances or are simply unconvincing in their plots. Many of the filmmakers here are young, in their twenties and thirties, and it may take a while yet before their productions can display the breadth and depth of maturity. Until that day arrives, however, films must continue to be made and it is encouraging that filmmakers and their investors are showing a willingness to explore and experiment.

Despite uncertain forecasts, several new releases other than the digital Return to Pontianak are expected in 2001. Included in the line-up are two more films by Raintree, the first of which is a Mandarin melodrama, The Tree, about the relationship between a mother and her son. The film stars Singapore's top TV actress Zoe Tay and award-winning Hong Kong actor Francis Ng. The second film, One Leg Kicking, is a joint venture with Cyberflics, produced by Eric Khoo who will also direct the comedy about an underdog who discovers himself through his sole passion, soccer.

Another production on the horizon is of a more gory nature. Titled Is It Murder?, the S $\$ 1$ million crime thriller is based on the book Murder is My Business by the late forensic pathologist Professor Chao Tzee Cheng. The film is financed by the new movie company CineArt Pictures and will star Hong Kong actor Ken Chao as Professor Chao. Whether or not the new batch of films will be good enough to entertain and be rewarded at the box-office, one can only wait and see and hope.

(This article is based on the author's text written for the catalogue of the Udineincontri Cinema Far East Film 2001)

\section{Author Information}

Yvonne NG is the co-author of Latent Images: Film in Singapore Second edition (NUS Press, 2010); Latent Images: Film in Singapore (OUP, 2000) and Latent Images: Film in Singapore CD-ROM (Singapore, 2003). She has written on Singapore and Asian cinema and contributes to the International Film Guide. 


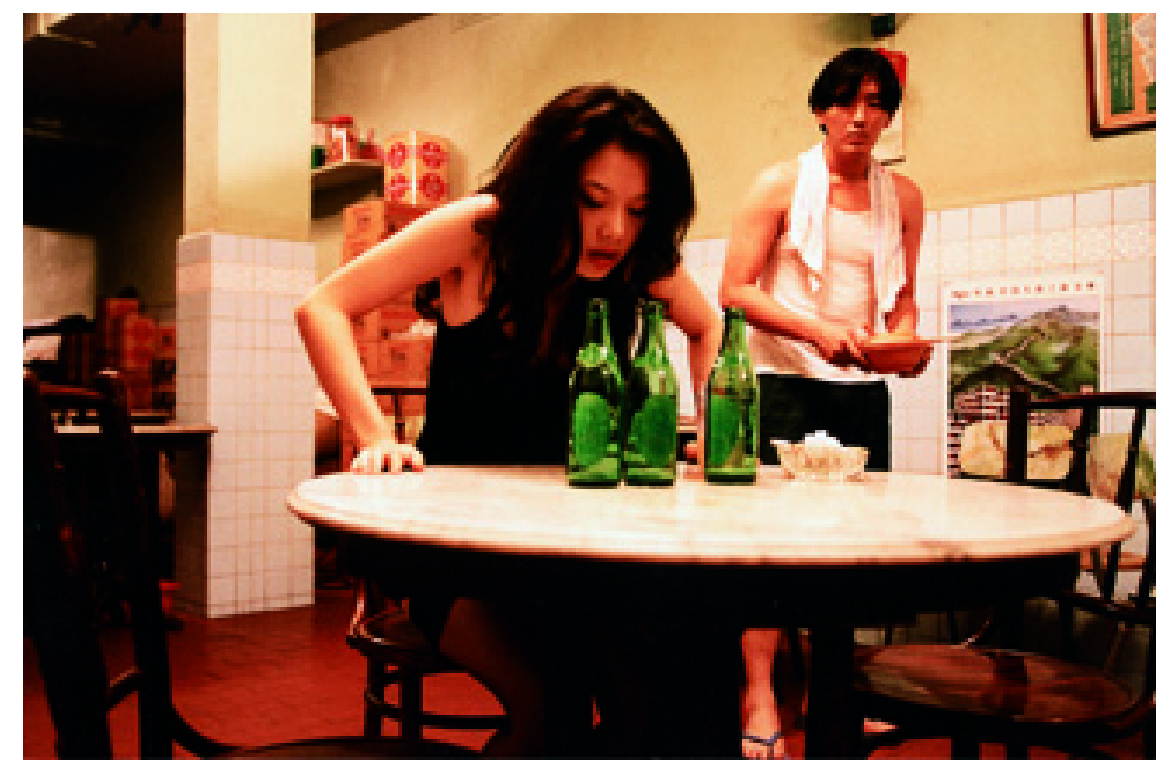

Figure 1: Mee Pok Man (dir. Eric Khoo, 1995) 